\title{
Majoring the Minor: Towards a Framework for Integrating Informal Industry into Formal Industry in Zimbabwe
}

\author{
Jerry Chigumbu \\ Africa University (PhD Student, Peace leadership \&Governance)
}

\begin{abstract}
There is global consensus on the centrality of the informal sector on economic growth. More importantly, the small to medium enterprises (SMEs) have become an important engine for economic growth for developing countries Zimbabwe included. This paper looks at the formalization of the informal sector in Zimbabwe. The argument being levelled is that continued growth of the informal sector without formalization of the informal enterprises has cantankerous ramifications on the economic growth, stability and industrial development. Overgrowth of the informal sector can be oxygen for the grey- market resulting in capital operating outside the formal financial systems thereby undercutting the economy. In this study, data was obtained through a critical review of various policy papers, academic articles on the subject area. Recommendations for formalization of the informal enterprises are made. The paper sets an agenda for the gradual formalization of deserving SMES through attaching it to and anchor industry that grooms the SME into the formal industrial practice.
\end{abstract}

Keywords: Words: informal sector, formalisation, economic development

DOI: $10.7176 / \mathrm{PPAR} / 10-6-06$

Publication date:June 30th 2020

\section{Background}

The birth of the concept of the informal sector in 1972 was accompanied by high optimism on its productive ability to catapult industrial development in developing countries through the utilisation of idle capital (De Soto, 1990). The failure of government policies to generate employment greatly resulted of informal SMEs in many developing countries. Mintah \& Darkwah, (2018) observed a rise in the informal sector in Africa over the past decade.Mwanza and Benedict (2018) estimates the contribution of the informal sector to towards the Gross Domestic Product at over 50\% in many African countries. Supporting Mwanza and Benedict (2018) position is ILO (2016) positing a $41 \%$ average contribution of the informal sector to the Sub Saharan Regional countries GDP, demonstrating the informal sectors criticality to the economic development of sub-Sahara African. Despite the varying importance of the informal sectors across the countries (Taiwo, et al, 2016), there exists a need for developing countries for anchor their industrialization agenda on the small to medium enterprises through the formalisation of the SMEs into full productive industries. The centrality of the informal sector contribution to the development of developing economies has attracted crucial policy debates towards employment creation and economic growth, however yet to generate finite solutions (Hart, 1973). However, a gape still exists on the comprehensive and pragmatic empirical and theoretical explanations that can fully explain the various issues on the full contribution and effects on the informal sector on sustainable economic development.

Since 1980, the informal sector has assumed many forms as it struggled to survive amid the laws imposed on their operations. Since independence, the informal sector in Zimbabwe has taken many shapes as the informal sector players have been forced to adjust to circumvent the restrictions, evictions, and by-laws imposed on their operations. It is estimated that the informal sector was $10 \%$ in 1980 and rose nineteen points up to $27 \%$ by 1991 (Ndiweni and Verhoeven 2013). Two significant events catalysed the growth of the informal sector in Zimbabwe. The informal sector was accelerated by the adoption of the Economic Structural Adjustment programs which resulted in massive closure of industries and retrenchments (Kawewe and Dibie, 2000). Ever since the growth of the informal sector has been unpreceded.

The second major economic event that created the informal sector was the economic meltdown that was typified by the 200-2008 hyperinflationary period with inflation rising to 79, 600, 00, 00\% by November 2008 . These two economic epochs stand firm in the creation of a large involuntary informal sector in Zimbabwe. Since then, the creation of the informal sector in Zimbabwe has been a mix of those who have been victims of the shrinking formal sector and those who could not find any formal job after education. To date, the informal sector in Zimbabwe has grown to compete out the formal sector. The problem being raised in this paper is the growth of the informal sector without a solid agenda for formalising the potential enterprises resulting in the informalisation of the economy. With $85 \%$ of the SMEs informal and unregistered, (FinScope, 2012) and $86 \%$ unbanked, transacting outside the formal banking system, this creates economic asymmetries. This scenario has led sustained grey-market activities that have negatively impacted on the formal industry. The formal industry cannot compete with the informal sector because the unregulated informal sector can afford trading at low prices while still making profits due to the absents of various tax, and compliance costs obligations. It may also explain why informal money trading outside the system is growing out of control with the Reserve Bank of Zimbabwe struggling to control 
inflation due to rates determined by the informal economy. Even formal companies are reaching out to the informal enterprises to sell their products and get cash or forex to finance their formal business to the extent that the black market has become the real market. This explains why the informal sector is growing and more money is circulating outside the formal system at the time the formal business is shrinking. An urgent need for downsizing the informal sector through a systematic gradual formalisation id proffered as one of the solutions to this economic conundrum.

\subsection{Conceptualizing informal sector, conceptual framework}

Over the last four decades, the contribution of the informal sector to development has attracted substantial attention to economic development policy especially with regards to poverty and unemployment reduction. Despite the coinage of the term "informal economy" in the 1970s, there seems to be no consensus on a universally accepted definition, (Bacchetta et al, 2009). The International Labour Organization (ILO) first defined the "informal sector" in 1972. Its characterisation was based on seven factors which include, labour-intensive and adapted technology, family ownership of enterprises, reliance on indigenous resources, ease of entry, acquisition of skills, reliance on personal resources and unregulated markets. The International Conference of Labour Statisticians (ICLS) proffered its definition with a thrust on the legal status of the enterprise. It thus refers to the informal sector as:

"Enterprises owned by individuals or households that are not constituted as separate legal entities independently of their owners, and for which no complete accounts are available that would permit a financial separation of the production activities of the enterprise from the other activities of its owner $(s)$ '”. (Hart, 1973).

The definition comprises activities that involve the provision of goods and services in exchange for remuneration, but which are not covered or are insufficiently covered by formal arrangements (ILO, 2002a). The definition captures unincorporated enterprises with unregistered paid employees that produce some unregistered goods for sale. Variability exists in terms of the number of employees in defining informal status. In Bolivia and Mexico, they use fewer than six and seven six (Prahan and Van Soest (1997), Central American economies use fewer than five, in Peru, fewer than six (Marcoullier et al. 1997), and fewer than 20 for Sudan and ten for Kenya (Livingstone (1991).

According to Ijaiya et al (2011), the informal sector covers a wide range of labour market activities either coping strategies or multiple job holding and unofficial earning strategies. To Meagher (2013) the informal sector simply refers to production and employment in unregistered enterprises. Williams sees it as "monetized exchange that is unregistered by or hidden from the state for tax, social security and/or labour law purposes but which is legal in all other respects" (Williams, 2011, p. 25). This absence of consensus shows the heightened attraction on the issue of the informal sector due to its centrality to development. There is no precise meaning of informal sector as it has remained a subject of controversy with many different meanings. This is because the concept informal sector has been defined to suit different contexts with different meanings (Hussmann, 2004). It can be noted that it is difficult to define conclusively the informal sector in a dichotomized manner because of the failure of size, registration, payment of taxes to discriminate sufficiently between formal and informal (Valodia and Davy, 2010). Thus the informal 1 sector continues to be more of a continuum of situations defined by a set of parameters that are often combined to determine the position of each firm along with the informality to formality scales. (Benjamin and Mbaye, 2014, Steel and Snodgrass, 2008).

\subsubsection{Theoretical framework}

A plethora of theories has been propounded to account for the existence of the informal sector in developing countries. From the morass of theories, the following theories were chosen for this paper. These include the rational choice theory, the structures' theory, The legalist theory, labour Supply theory. Table 1.1 illustrates the theories mentioned: 
Table 1. The capitals, assets and revenue in listed banks

\begin{tabular}{|c|c|c|}
\hline Theory & Main Proponents & Main tenants \\
\hline Theory & Main proponents & Main Tenants \\
\hline $\begin{array}{l}\text { The Dualist } \\
\text { Theory }\end{array}$ & $\begin{array}{l}\text { The International } \\
\text { Labour Organisation; }\end{array}$ & $\begin{array}{l}\text { 1. informal economy is characterized by marginalized economic } \\
\text { activities that are dominated by the poor as a source } \\
\text { of income and a safety net in a period of economic meltdown } \\
\text { 2. the existence of the informal sector is attributed to the } \\
\text { unavailability of enough formal job opportunities being created to } \\
\text { take up surplus of labour. }\end{array}$ \\
\hline $\begin{array}{l}\text { Structuralist } \\
\text { Theory }\end{array}$ & $\begin{array}{l}\text { Portes et al, } 1989 \\
\text { popularized the } \\
\text { structuralist theory in } \\
\text { the } \\
\text { late } 1970 \mathrm{~s} \text { and early } \\
1980 \mathrm{~s}\end{array}$ & $\begin{array}{l}\text { 1.informal sector should be viewed as part of the global economic } \\
\text { system that } \\
\text { serves to reduce input and labour costs indirectly increasing the } \\
\text { competitiveness of large corporations } \\
\text { 2. theory acknowledges the co-existence between the formal and } \\
\text { informal sectors. } \\
\text { 3. It again explains the linkages, the inter-connectedness and inter- } \\
\text { dependency that ensure that the informal sector is a necessary } \\
\text { component of the global economy. }\end{array}$ \\
\hline $\begin{array}{l}\text { The Legalist } \\
\text { theory }\end{array}$ & $\begin{array}{l}\text { Feigie (1981) and de } \\
\text { Soto } \quad(2000) \\
\text { popularised } \\
\text { the legalist theory. }\end{array}$ & $\begin{array}{l}\text { legalist theory is a result of exorbitant, inefficient, } \\
\text { cumbersome and costly government rules and regulations, which } \\
\text { makes it hard to comply and micro-entrepreneurs tend to go informal }\end{array}$ \\
\hline $\begin{array}{l}\text { The Rational } \\
\text { Choice Theory }\end{array}$ & $\begin{array}{l}\text { Schneider and Enste } \\
(2000)\end{array}$ & $\begin{array}{l}\text { assumes that individuals always want to maximize their satisfaction } \\
\text { given the available information on the benefits and costs of their } \\
\text { action } \\
\text { 2. there are } \\
\text { many factors and reasons influencing individuals } \\
\text { to formalize or to stay informal, highlighting that } \\
\text { though economic factors should be given more } \\
\text { weight, personal issues should not be ignored as } \\
\text { well. }\end{array}$ \\
\hline $\begin{array}{l}\text { The Rationalist } \\
\text { Legalist theory }\end{array}$ & Jamela, 2013 & $\begin{array}{l}\text { micro-entrepreneurs consider the social and opportunity costs } \\
\text { involved before opting to go formal }\end{array}$ \\
\hline $\begin{array}{l}\text { The Recession } \\
\text { Push Theory }\end{array}$ & $\begin{array}{l}\text { Uribe-Echevarria, } \\
\text { 1993). }\end{array}$ & $\begin{array}{l}\text { The theory postulates that, in times of recession, large-scale } \\
\text { enterprises are more affected than small and medium enterprises } \\
\text { with many employees who would have suffered from the painful } \\
\text { strategies of retrenchment, downsizing, rightsizing and realignment } \\
\text { being forced to start their informal SMEs }\end{array}$ \\
\hline $\begin{array}{l}\text { The labour } \\
\text { supply theory }\end{array}$ & $\begin{array}{l}\text { Pedersen } \\
(1998)\end{array}$ & $\begin{array}{l}\text { SMEs' development is attributed as a response to the high levels of } \\
\text { unemployment and it acts as a solution for the employees who } \\
\text { cannot be absorbed in the formal economy. }\end{array}$ \\
\hline
\end{tabular}

These theories converge at various levels to explain the various scenarios that have led to the creation and sustenance of the informal sector in Zimbabwe. The ideal theories to the explanation of the serious development in Zimbabwe are the legalist theory, the recession push theory and the labour supply theory.

\subsubsection{Drivers of Informal Activities}

There are various drivers of informal activities. Scholars identified a plethora of reasons that explain the growth of the informal sector which include among other factors weak institutions, retrenchments, uncommitted governments, economic hardship and poverty (Onwe, 2013). Corruption and bad governance have been identified as the main drivers of informal sector participation in Nigeria. Igudia et al., (2016) identified corruption and poor governance as key drivers in Nigeria. Studies by Sookram (2008) on Small-Business Participation in the Informal Sector of an Emerging Economy' established tax eversion, easiness of entry and regulatory nature of the informal sector as key drivers in Trinidad and Tobago. These factors vary across regions and countries. They are shaped by various social, economic and political factors prevailing in the country. However, commonalities exist along with the identified factors.

\subsubsection{Growth of the Informal Economy in Zimbabwe}

The growth of the informal sector owes much to the kaleidoscopic political and economic atmosphere that 
prevailed after 1990. Between 1980 and 1990, the informal sector was at 10\%. The rate escalated with the adoption of ESAP and the subsequent economic deterioration that marked the economic landscape of Zimbabwe to date. Sakuhuni (2014) liked the causes of the informal economy to ESAP, economic meltdown, poverty, internal migration, famine and a desire to have an alternative means of survival and bid to enjoy tax freedom. In 2002 , the ILO traced the growth of the informal economy to: out of bounce

'...inappropriate, ineffective, misguided or badly implemented macroeconomic and social policies, often developed without tripartite consultations; the lack of conducive legal and institutional frameworks; and the lack of good governance for proper and effective implementation of policies and laws.'

Muchichwa (2017) traces the rise of the informal economy to the rise in urban population by an average of $8 \%$ per annum increase failing the urban formal economy to keep pace with the growth, the adoption of the ESAP in 1991 resulting in the liberalization of the economy, the collapse of the domestic industrial sector, and massive layoffs. The 1997-2008 economic crisis/meltdown (1997-2008) resulting in massive retrenchments and business closure most business operating well below full capacity levels, resulting in the in formalisation of the economy (Muchichwa, 2017, Munangagwa, 2009).

It can be noted that both ESAP and the economic collapse led to the laying off of skilled personnel into the informal sector (Kanji \& Jazdowska. 1993). Thus it must be noted that the type of the informal worker in the Zimbabwean economy is typified by a concentration of highly skilled personnel laid off buy the formal employment sector. The Standard Newspaper (2014) reported that an estimated 300000 students were churned out of schools, colleges and universities every year to join millions already unemployed. All these found themselves in the informal sector. The limited capacity of the shrinking formal economy to absorb surplus-labour, failure of industrial development to create adequate employment for the rising job seekers (Rupani, 2014), increased rate of urbanization due to rural-urban migration, the sustained economic collapse forced surplus labour to migrate to the informal sector.

\subsubsection{Informal sector as an engine for economic growth.}

Various scholars have pontificated on the informal sector as an engine for economic growth (Rasheed et al, 2019; Mpofu, 2017). The informal sector contributes 70\% of the GDP in Ghana (ITC, 2016), $70 \%$ in Zambia creating $88 \%$ of employment and 3\% of the GDP in Kenya (African Economic Review, 2017). This is because of its ability to incubate industry. The informal sector provides enough testing ground for industrial development. Attia (2009) sees the informal sector as an engine for poverty reduction and development because of its ability to accelerate economic growth and reducing inequalities. The need is there to capitalize on the existence of the informal sector by taking both regulatory and policy steps towards creating an enabling environment for the formalization. This is because formalization brings more benefits that enhance the sustainability of the enterprise. This will help to set the deserving informal industries on a path of formal industrialization. Continued existence and growth of the informal sector without integrating deserving enterprises into the mainstream industry has cantankerous ramification on the economy. The overgrowing of the informal sector has the negative ability to pull off capital from circulating through formal channels and circulating through the grey market which affects economic development. It is for this reason why a continued integration and formalization of the informal sectors be prioritised.

\subsubsection{Towards a framework for integration}

The informal sector is a transitory phenomenon that should be absorbed into the mainstream formal industrial sector. According to the Fin Scope MSME Survey (2012), 5.7 million people working in the sector, 2.8 million of whom were business owners and 2.9 million were employees. The study established that $85 \%$ of the MSMEs were neither registered nor licensed, and only $15 \%$ were registered vised and licensed (FinScope, 2012).

This scenario presents the Zimbabwean economy with various opportunities for industrial development. Historically, the informal sector was thought to be comprised of small enterprises, street vendors, shoe repairs and all types of relatively small and hard to tax groups. However, current trends show that professionals like engineers, lawyers, teachers and economists are operating in the hidden economy of Zimbabwe. Given that most of the workers in the informal sector are those skilled workers who were victims of industrial collapse and trained graduates who could not find employment, a window of opportunity exists for formalizing their enterprises and integrating them into the mainstream formal industry. There is need for reorganizing the informal sector, categorize it and create sustainable opportunities for formalization and professionalization.

\subsubsection{Steps towards integration}

First, there is a need for the government of Zimbabwe through the responsible ministries to create a comprehensive database of the functioning and closed industries. A needs analysis of the functioning industries will provide information on their products profile and product development processes. This will help to identify the stage and level upgrade informal sectors industries may be fit in in a gradual process. 
Second, there is a need for creating a database of the informal industry capturing the nature of the industry, skills levels, product line and their target market and skills levels. This stage is very important in categorizing and classifying the enterprise.

The third phase involves the matching of the selected informal industry and formal industries (anchor industries) that are in the same line of production. In this process, the informal industry is made to fit in the production line of the formal industry. The condition for timely and quality products are set by the formal industry. This forms the part of the regularization process. Guidance and grooming are provided by the anchor formal industry. For example, a furniture manufacturing industry may groom a group of informal SMEs and task it to produce the base mainframes for sleeping beds or lounge sofas only. The formal anchor firm would finish up the upholstery and direct the finished product to its market. In this, the informal industry invited will be gradually configured into the formal industry.

This entails that the anchor Industry (formal industry) will provide the market for the attached informal industry. This will help the informal industry to have access to markets and capital as well as setting the terms on a path of formalization. This will also help to redirect capital from the grey market rerouting it into the formal systems thereby adding value into the mainstream economy. In Zimbabwe, the FinScope (2012) established that $85 \%$ of the MSMEs were neither registered nor licensed, giving an estimated US\$7.4 billion potentially circulating outside the formal banking system. Only $14 \%$ of the SMEs owners are banked and $50 \%$ of informal business owners (1.4 million) use the informal mechanisms to manage their business finances. Hence, the government can diffuse the problematic black market through the formalisation of the SMEs which are currently the major players in circulating capital outside the formal market, because of little or no link with the formal banking system.

\subsubsection{Conditions for formalization and future policy direction for SMEs formalization in Zimbabwe.}

Formalization is the process of legitimizing the informal sector production into the formal sector. This has many advantages for both the economy and the enterprise. The formalizing informal sector brings in capital into the formal system. This will increase the capacity of the Ministry for landing capital to the SMEs as loads for productive purposes resulting in the gradual recapitalization of the incubated SMEs and their path to formalisation. In brief, formalisation can take different forms including registering and taxing informal sector, providing business incentives and support services to SMEs, securing legal and social protection for the informal workforce and enabling the SMEs to participate in policymaking and collective bargaining processes. The following framework is therefore tendered for the formalisation process:

(a)Formal registration as a full company

Various conditions should be met by incubated enterprises. First, the selected entropized need to go through a registration process. This is an important step towards formalization. Registration brings in and confirms the legal status of the enterprise. It is only when registered that the enterprise becomes eligible for matching with an anchor industry.

\section{(b)Formal company structure}

Corporate governance requires that the enterprise create formal corporate structures that facilitate the discharge of good governance in the enterprise. According to Sun (2016), corporate governance is the way institution policies itself thru instating its customs, policies and laws to its employees from the highest to the lowest levels. Prem (2014) and Maharaj (2011) point out the need for corporate governance irrespective of the size of the institution. To SMEs, this entails the creation of relevant structures and departments within the leadership. With the guidance of the anchor industry and the ministry, the configuration of structures that enhance good governance can be achieved gradually as the enterprise achieves full integration into the formal industry. Statures that promote transparency, accountability, record keeping and management as well as the holding of management meetings must be created (Radebe, 2017).

(c) Tax compliance

Once registered the entries should be tax complete. This is done to orient enterprise towards good governance and fulfilling regulatory requirements. It is also important as justification for receiving state loans and financial assistance as afforded other formal companies. More so such compliance creates confidence for financial institutions.

(d) Compliance with labour laws

Compliance with labour laws and working conditions for workers is also important in the formalization process. Studies by Uzhenyu and Marisa (2017) established a lack of basic lack of knowledge of industrial and labour laws among SMEs in Zimbabwe. Fulfilment of this condition is gradually expected as the incubated entries grow ad gradually formalizes. The joining relevant industrial regulatory boards are expected as deemed right by the anchor industry. This helps the particular enterprise to operate within the guidelines of the industry and thus enhances the acceptance of its products into the market.

(e)Financial inclusion

The informal sector is a key driver of capital. Enforcing compliance in financial inclusion is paramount to reduce 
financial haemorrhage into the informal system. In Zimbabwe over 7.4 billion circulated outside the formal system through the informal sector, (FinScope, 2012). Compliance with financial inclusion presents a platform for good corporate governance and full contribution into the national economic system. Studies by Rasheed et al (2019) in SMEs in India showed that the SMEs that embraced financial inclusion through digitization performed better than those using traditional means. However, studies show a high reluctance of financial institution to provide services SMEs. Therefore, mitigating this negative perception on the bankability of SMEs should constitute part of increasing access of SMEs to finance. Studies by Mpofu (2017) on SMEs in Zimbabwe show that SMEs have limited access to finance low financial literacy. Shinozaki (2012) views access to finance as a not only important for the survival of the SMEs but also as a way of growing out of the SME status to a bigger formal industry.

(f) Market research

Most informal industries depend on an unfeasible market. Most of the market used is a grey market. This limits the maximization $\mathrm{n}$ of the profits resulting in the enterprise failing to post sustainable profits to recapitalize and grow into a formal industry. When linked to the formal anchor industry, the anchor becomes the ready market for the enterprise. This improves the predictability of the volumes needed by the market as well as revenue inflows. (g) Quality control

The anchor is charged with the responsibility for maintaining quality on the products produced by the enterprise. This together with the meeting the quality standards as set by the regulatory industrial that regulates the practice of that associated that particular will help meet the quality

(h) Recapitalization of machinery and skills training

While acknowledging the inherent skills already existing in the informal works because some of them were once in industries before retrenchment, there is need for updating the skills so that they are compliant with new quality and best practices required in the industry. More so, the ever-evolving technology required updating the human's skills base to improve production and efficiency resulting in the production of high quality of products that are acceptable by the anchor industry and the target market.

\subsubsection{Conclusion}

There is no doubt that the informal sector remains an engine for economic growth. Its potential ton generate employment and incubate enterprises which can later develop into full formal industries cannot be underestimated. However, the uncontrolled and unregulated informal sector can become a risk to both the formal and the whole national economic development due to its potential to harbour grey-market activities that undercut the gains of economic development. This paper highlighted the importance of the informal sector as well as a framework for formalisation as a panacea to the problem.

\subsubsection{References}

Attia, S.A (2009) The informal economy as an engine for Poverty reduction and development in Egypt.https://mpra.ub.uni-muenchen.de/13034/1/Microsoft_WordInformal_Economy_as_an_engine_of_Development_in_Egypt.pdf

Becker, K. F. (2004). The Informal Economy. A Fact-Finding Study. Swedish International Development Cooperation Agency (SIDA), Stockholm, Sweden, March 2004.Retrieved from http://www.rrojasdatabank.info/sida.pdf

Bacchetta, M, Ekkehard, E, and Bustamante, P, J (2009), A joint study of the International Labour Office and the Secretariat of the World Trade Organization, 2009 International Labour Organization and World Trade Organization, Geneva, Switzerland

De Soto, H. (2000). The Mystery of Capital: Why Capitalism Triumphs in the West and Fails Everywhere Else. New York: Basic Books.

Feigie, E. (1981). The UK's Unobserved Economy: A preliminary assessment. Economic Affairs, 1(4), $205-212$. https://doi.org/10.1111/j.1468-0270.1981.tb00939.x

FinScope Survey on Micro, Small to Medium Enterprises (2012), Fin Mark Trust.

Hussmanns, R. (2004). Measuring the Informal Economy: From Employment in the Informal Sector to Informal Employment (ILO Policy Integration Department / Bureau of Statistics, ILO Working Paper No. 53). Geneva. Retrieved from http://www.ilo.org/wcmsp5/ groups/public/---dgreports/--integration/documents/publication/wcms_079142.pdf

Hart, K., (1973), Informal Income Opportunities and Urban Employment in Ghana. The Journal of Modern African Studies, 11(1), 61-89.

International Trade Centre (2016). SME Competitiveness in Ghana: Alliances for Action. ITC, Geneva.

Ijaiya, G.T et al (2011). Poverty in the Urban Informal sector of Kwara state Nigeria. University of IIorin Senate Research Grant Report 201.

Igudia, E., Ackrill R., Coleman, S and Dobson, C. (2016). Determinants of the informal economy of an emerging economy: a multiple indicator, multiple causes (MIMIC) approach. International Journal of Entrepreneurship 
and Small Business, 28, 11-18.

International Labour Organisation (ILO) (2016). Transforming Jobs to End Poverty, World Employment Social Outlook (WESO). International Labour Office, Geneva. Retrieved from http://www.ilo.org/global/research/global-reports/weso/2016-transforming-jobs/WCMS_481534/lang-en/index.htm

Jamela, T. (2013). Experiences and Coping Strategies of Women Informal Cross Border Traders in unstable political and economic conditions: The Case of Bulawayo (Zimbabwe) Traders (Master thesis in Development Studies). University of Johannesburg. Retrieved from https://ujcontent.uj.ac.za/vital/access/services/Download/ uj:7483/CONTENT1

Kawewe, S, M. and Dibie, R. (2000) "The Impact of Economic Structural Adjustment Programs [ESAPs] on Women and Children: Implications for Social Welfare in Zimbabwe, "The Journal of Sociology \& Social Welfare: Vol. 27: Iss. 4, Article 6. Available at:https://scholarworks.wmich.edu/jssw/vol27/iss4/6

Kanji, N., \& Jazdowska, N. (1993). Structural Adjustment and Women in Zimbabwe. Review of African Political Economy, (56), 11-26. Retrieved June 2, 2020, from www.jstor.org/stable/4006121

Livingstone, I. (1991), “A reassessment of Kenya's rural and urban informal sector”, World Development, 19(6): 651-670.

Meagher, K. (2013). Unlocking the Informal Economy: A Literature Review on Linkages Between Formal and Informal Economies in Developing Countries, Women in Informal Employment: Globalizing and Organizing WIEGO Working Paper No 27, April 2013, UK

Muchichwa, N. (2017). Decent Work in the informal Economy: Towards Formalization of the Informal Economy. Labour and Economic Development Research Institute of Zimbabwe (LEDRIZ)/Friedrich-EbertStiftung(FES), http://library.fes.de/pdf-files/bueros/simbabwe/13742.pdf

Mbaye, A.A. and N. Benjamin, (2014). "Informality, Growth and Development in Africa," in J. Lin and C. Monga editors, The Oxford Handbook of Africa and Economics.

Marcoullier, D., Ruiz de Casilla, V. and Woodruff, C. (1997), "Formal measures of the informal-sector wage gap in Mexico, El Salvador, and Peru", Economic Development and Cultural Change, 45(2): 367-92.

Mwanza, P. S., \& Benedict, H.O. (2018). Challenges in UtilisingBudget among SMEs in the Manufacturing Sector is the Cape Metropole. Entrepreneurship \& Organisation Management, 7(1)

Mintah, S. and S. Darkwa, S. (2018), Drivers of Informal Sector Participation of Small and Medium Enterprise in Ghana,Scientia Agriculture Bohemia, 49, 2018 (1): 60-67.DOI: https://doi.org/10.2478/sab-2018-001

Mpofu, O. (2017) Could it be a case of Financial management ignorance? An analysis of Strategies employed by SMEs in Zimbabwe. Global Journal of Interdisciplinary Social Sciences, Volume 6(4)20-25.

Munangagwa, C, L. (2009) "The Economic Decline of Zimbabwe, "Gettysburg Economic Review: Vol. 3, Article 9. Available at:https://cupola.gettysburg.edu/ger/vol3/iss $1 / 9$

Ndiweni, E. and Verhoeven, H. (2013) 'The rise of informal entrepreneurs in Zimbabwe: evidence of economic growth or failure of economic policies?', African J. of Accounting, Auditing and Finance, Vol. X, No. Y, pp.000-000.

Maharaj, A. (2011). Corporate Governance and Small Businesses. Retrieved from http://www. corporate secretary.com/articles/ boardrooms/11483/corporate-governance-sm... (accessed on April 13, 2016).

Pradhan, M. and van Soest, A. (1995), "Formal and informal sector employment in urban areas of Bolivia", Labour Economics, 2: 275-297.

Portes, A., \& Castells, M. (1989). World Underneath: The Origins,Dynamics and Effects of the Informal Economy. In A. Portes,M. Castells \& L. A. Benton (Eds.), The Informal Economy. Studies in Advanced and less Developed Countries (pp. 11-33). Baltmore: John Hopkins University Press.

Prem, M. (2014). Simple ways SMEs can implement corporate governance structures. SME South Africa.

Pedersen, P. O. (1998). The Role of Small Enterprises and Small Towns in the Developing Countries (CDR Project Paper 89). Centre for Development Research: Copenhagen.

Rasheed. S.H, Mahood, I., Khan S.N (2009) Financial Inclusion for SMEs: Role of Digital Micro financial services, Review of Economics and Development Studies , Volume 5: No. 3, 2019.

Radebe M. S. (2017). The benefits of good corporate governance to small and medium enterprises (SMEs) in South Africa: A view on top 20 and bottom 20 JSE listed companies. Problems and erspectives in Management, 15(4), 271279. doi:10.21511/ppm.15(4-1).2017.11

Steel, W. and Snodgrass,D. (2008). "Raising Productivity and Reducing Risks of Household Enterprises": Diagnotic Methodology Framework, World Bank.

Schneider, F., \& Enste, H. (2000). Shadow Economy: Theoretical Approaches, Empirical Studies and Political Implications. Cambridge (UK): Cambridge University Press.

Sookram S, and Watson PK (2008): Small-business participation in the informal sector of an emerging economy. The Journal of Development Studies, 44, 1531-1553.

Shinozaki, S. (2012) : A New Regime of SME Finance in Emerging Asia: Empowering Growth-Oriented SMEs 
to Build Resilient National Economies, ADB Working Paper Series on Regional Economic Integration, No. 104, Asian Development Bank (ADB), Manila, http://hdl.handle.net/11540/1260

Sun,L.(2016).Why Is Corporate Governance Important?

Retrieved from http://www.businessdictionary.com/article/618/why-is-corporategovernance-is-important/ (accessed on April 13, 2016).

Taiwo, J. N., Onasanya, A. Y., Agwu, M. E., \& Benson, K. N. (2016). The Role of Microfinance Institutions in Financing Small Businesses. Internet Banking and Commerce, 21(1), 1-20

Uribe-Echevarria, F. (1993), Changing Policy Regimes for Small-Scale Industries in Latin

America: Lessons for Africa. In A.H. J. Helmsing \& T. Kolstee (Eds.), Small Enterprises and Changing Policies: Structural Adjustment, Financial Policy and Assistance Programs in Africa. Intermediate Technology Publications: London.

Uzhenyu, D and Marisa, J. (2017) Non-Compliance with Labour Legislation by Registered Small to Medium Enterprises in Harare Jeopardizing Industrial and Labour Relations, IOSR Journal of Business and Management (IOSR-JBM) e-ISSN: 2278-487X, p-ISSN: 2319-7668. Volume 19, Issue 10. Ver. IX. (October. 2017), PP 67-73 www.iosrjournals.org

Valodia, I. \& Devey, R, (2010). Formal-informal economy linkages: What implications for poverty in South Africa? Law, democracy \& development14: 1-26.

Williams, C (2011). Explaining the persistence of the informal economy in Central and Eastern Europe: some lessons from Moscow. Journal of Economy and its Applications, Vol. 1 Issue 1 (2011), pp. 22-52. 